\title{
Soeharto's Indonesia: A Better Class of Corruption
}

\section{Ross H. McLeod}

I ndonesia has a reputation as one of the most corrupt countries in the world (Transparency International, 1999). Unlike many others that are regarded as highly corrupt, however, this was not incompatible with rapid economic progress over three decades, and Soeharto's New Order regime clearly brought considerable material benefits to the majority of the population. Some argue that endemic corruption was unsustainable and that it was responsible for the unravelling that has been seen since mid 1997, but while the nature of government-business relationships undoubtedly contributed in important ways to the crisis, the mechanisms by which this occurred have yet to be adequately described. The present paper attempts to fill this gap.

\section{The Political Economy of the Rent-Generating Government}

A quarter of a century ago, Anne Kreuger's (1974) seminal paper focused our attention on the phenomenon of 'rent seeking' behaviour, and implied that much of the blame for corruption in developing countries 'lies with the proliferation of economic controls following independence' (p.293). However, apart from noting the possibility of a political 'vicious circle' in which intervention followed by rent seeking would generate more intervention, Kreuger had nothing to say about the reason for the initial intervention.

The notion that ill-advised intervention leads to rent seeking and corruption and that endemic corruption caused the crisis suggests that crises can be avoided by eschewing such intervention, and encourages the view that crises already underway can be cured by getting rid of it. The latter view seemed to motivate the long and inappropriate list of policy changes that the International Monetary Fund (IMF) demanded of Indonesia early in the current crisis (McLeod, 1998:45-7).

The following discussion turns the Kreuger notion of rent seeking as an unintended response to intervention on its head, however, seeing intervention instead as the means of deliberately generating and capturing rents. Thus the view to be explored here is that the substantial government intervention that existed under Soeharto was in no sense an accident, but was consciously put in place for the purpose of generating the rents that Soeharto presumably wanted for their own sake, and also needed in order to first attain and then maintain a position of virtually unchallenged authority.

Ross McLeod is a Fellow in the Indonesia Project at The Australian National University. 


\section{The Soeharto-Business Symbiosis}

It is helpful to think of an autocrat such as Soeharto became as having the power privately to tax economic activity in general. In the chaotic period before he came to power (in the aftermath of the attempted coup against President Sukarno in 1965) the tax base had shrunk drastically, so the first challenge was to resurrect the economy from the crisis of hyperinflation it was then undergoing. Once the golden goose was again in good health, all that remained was to feed it well, collect the golden eggs it laid, and ensure that it did not escape from the owner's backyard.

Although the economy was then in a calamitous state, it was endowed with an abundance of natural resources, a huge population and a cheap labour force, all of which made it attractive to investors, including foreign investors. At the same time, the West was anxious to consolidate the move away from communism, to which Indonesia had become uncomfortably close under Sukarno. Given these circumstances it proved possible to revive the economy in a relatively short time by opening it to largely unfettered foreign investment (Sadli, 1993:43), and by welcoming a large inflow of international aid (Hill, 1996:78-81). Indeed, Soeharto exploited both these sources of funds with great skill throughout his entire term in office.

Soeharto also inherited a large state enterprise sector involved in many fields of activity. This was useful in several ways. First, state-owned enterprises (SOEs) could be used to provide jobs for members of the armed forces upon their retirement from active duty, thus helping to ensure their loyalty to, and dependence on, the regime. Second, they could be used in similar fashion to provide jobs for relatives and friends of other Soeharto supporters, such as his ministers and senior bureaucrats. Third, they could be used to absorb high level military personnel who were potential threats to Soeharto's authority. (Thus the SOEs came to employ ex-military men at all levels, from security guards to managing directors and commissioners.) Fourth, they could be used as cash cows - by way of overpriced contracts with suppliers and under-priced contracts with customers.

In one way or another, the private corporate sector provided the primary medium through which Soeharto generated his family's enormous wealth and maintained his own power. Early on he realised the effectiveness of private sector monopoly privileges for generating rents. The earliest prototype emerged in 1968 - the first year of the New Order. It involved the restriction on imports of cloves - an essential component of Indonesia's kretek cigarettes - to just two firms, one owned by Soeharto business associate and now Indonesia's richest citizen, Liem Sioe Liong, and one by Soeharto's half-brother, Probosutejo (Backman, 1999:114; McDonald, 1980:120-21).

Such monopolies usually had some spurious national interest rationale for the sake of appearances, but in the absence of a free press and an effective parliament, few voices were raised in opposition to them. Their purpose was to generate rents that were then shared between the favoured recipients and Soeharto and his 
family, or his supporters and theirs. Although there may be little evidence of anything so crude as direct payments as quids pro quo, it is surely no coincidence that members of the first family came to be significant shareholders in the many firms that benefited from some kind of privilege granted by the government (Robison, 1986:343-50; Backman, 1999:255-99). ${ }^{1}$ Another technique for harvesting the rents generated by these privileges was for the favoured firms to 'donate' large sums to a number of foundations (yayasan) - tax-free entities cloaked as charitable institutions of one kind or another - controlled by Soeharto, and whose funds were deployed for purposes known only to himself.

\section{Aspects of the Soeharto system of rent generation}

Various important features of Soeharto's Indonesia can be explained within the framework just outlined.

\section{Centralisation of power}

The Soeharto pattern of rent extraction at the commanding heights of the economy was successful, but for him to maintain his position as leader he would need plenty of support and not too much active opposition. Moreover, since the bulk of economic activity involved large numbers of relatively small. firms, it would not be practicable for him to maximise the flow of rents unless rent generation and harvesting could be replicated at lower levels. The solution was a system akin to business franchising - or what Crouch (1979) has referred to as 'patrimonialism'. Just as Soeharto used his position as head of the national government to bestow privileges on selected firms ('cronies', as they have come to be known), so he effectively awarded franchises to other government officials at lower levels to act in similar manner. This included many of his ministers and senior bureaucrats, government administrators at all levels - from provinces down to rural villages - and top executives in the state enterprises and special government bodies such as the food logistics agency, Bulog, and the Agency for the Study and Application of Technology.

These franchises were not awarded free of charge, of course: as with orthodox business franchises, there had to be benefits to both franchiser and franchisee. The payback could be in a multitude of forms: payment to a Soehartocontrolled yayasan; the provision of loans and award of contracts on favourable terms to first family members and business cronies by state banks, state enterprises, and government departments; a flow of information to the top regarding individuals or organisations that might threaten the existence of the system; a willingness to act against such individuals and organisations in order to protect it; and of course clear loyalty to the head of the franchise whenever there might be a public outcry about the way the country was being governed.

Soeharto's late wife, Tien, was popularly known as 'Madame Ten Percent', nevertheless, reflecting the widespread belief that an official signature on a contract could be bought for 10 per cent of the contact price. 
This is not to suggest that all Soeharto appointees, all members of the bureaucracy, and all employees of the state enterprises played an active role along these lines. All that was necessary was that there should be sufficient people willing to play the game so that opportunities for harvesting rents could be optimally exploited, and that those who might otherwise have opposed what was going on would have a good deal to fear from stepping out of line - whether in terms of forfeited promotion prospects or loss of their positions. Moreover, there were those who knew clearly what was going on and wanted no part of it, but thought that they had a better chance of changing the system for the better from within. A small number of officials had the courage to take a principled stand on various occasions during the three decades of the New Order, and suffered as a consequence, providing a cautionary example for others of like mind (Kenward, 1999a:85; Schwarz, 1999:149). Thus the endemic corruption at all levels of the bureaucracy should not be interpreted as an unintended shortcoming of Soeharto's Indonesia. Rather, it reflected a conscious effort to generate and harvest rents from business (and, to a lesser extent, from individuals) at all levels.

\section{Rule of law}

To say that the rule of law under Soeharto was weak would be a gross understatement. Black letter law was largely a relic of the colonial era, and little effort was made to bring laws up to date or to introduce new laws in areas where modernisation of the economy and polity made this highly desirable. But it was not the case that written law was useless: one can travel by horse-drawn cart, even if not with the speed and comfort of an air-conditioned car. The more serious problem was the ineffectiveness of law enforcement and the courts. Policemen rarely arrested or charged traffic offenders, supervisory officials rarely punished firms that violated regulations, and commercial disputes were rarely taken to the courts to be settled. Judges, public prosecutors, police and regulatory supervisors were all either Soeharto franchisees or else felt powerless to take a stand against the system.

None of this should be seen as an oversight, nor was the system anarchic. In the absence of properly functioning formal law, informal law naturally tends to take its place. The vacuum was filled by informal arbitration, with Soeharto and his civil service and military franchisees playing the role of arbitrators and enforcers. Just as judges could enrich themselves by selling their judicial decisions, so Soeharto and his other franchisees could do so by making 'determinations' outside the courts that put an end to all kinds of matters in dispute.

\section{Reliance on the military}

Soeharto made skilful use of the military, having demonstrated in 1965-66 that he would not hesitate to use it in the most brutal fashion against forces or groups that did not play by his rules (Crouch, 1979:575-6). Hundreds of thousands were murdered for the 'crime' of having supported the Communist Party (the main 
political party to oppose the military in seeking to determine Indonesia's political direction under Sukarno) while the military stood by and gave its tacit support (Cribb, 1990). (Similar behaviour was observed more than three decades later in East Timor, after a large majority of its population voted for independence in August 1999.) Thousands of others were recorded as having had links to the Communist Party, and were jailed or at least excluded from participation in the bureaucracy. Indeed, even the children of such people were so excluded, for decades to come. And at times when other groups threatened the integrity and continuity of the regime - separatists in Aceh, East Timor and Irian Jaya, university students, militant labour, thugs and extortionists working outside the franchise - Soeharto did not hesitate to unglove the iron fist of the military (see for example McDonald, 1980:127).

\section{Civil and military salaries}

One of the most obvious explanations for the immense and widely acknowledged shortcomings of the Indonesian civil service is its salary structure. By comparison with the private sector where wage and salary rates reflect supply and demand, this structure is extremely compressed, with salaries of the very top officials only a relatively small multiple of those of clerks and office assistants with minimal education and skills. At the bottom end wage rates have been, if anything, above market, meaning that there has never been any difficulty in recruiting individuals for these sorts of positions. Indeed, there has usually been an excess supply of applicants, and low level officials of personnel departments have not been slow to exploit the franchise right to harvest the rents from those keen to win secure jobs in the civil service and state enterprises.

At the top end, however, salaries have always been woefully inadequate - a small fraction of those available in the private sector for people with the levels of training and skills required in order to do these jobs properly. The result was not that there was any difficulty finding people to fill the positions, however. This could never be a problem, given the large numbers who made up the lower echelons, and who waited patiently for those at higher levels to retire or die and thus give them a chance of moving up the ladder. Rather, the problem has been that the people who moved up were to a large extent those who demonstrated by their conduct over many years that they were worthy of being awarded a Soeharto franchise - and, in many cases, who were willing to pay those who controlled promotions in order to be looked upon favourably.

In short, the system was designed precisely in order to attract and recruit people who were willing and able to play the game by Soeharto's rules. The eagerness to opt for a lowly paid civil service or military career, to pay bribes (in cash or in kind) to get a foot in the door, and to pay bribes again in order to get promotions, is most easily understood in the context of a system in which everyone knew that the civil service, the military and the state enterprises were all part of a huge franchising operation, in which one could expect to become increasingly wealthy if one signed on to the implicit franchise contract. 


\section{Rent generation}

As Harrison (1966) wrote in relation to the taxation issue in the UK in the 1960s,

If you drive a car I'll tax the street,

If you try to sit I'll tax the seat,

If it gets too cold I'll tax the heat,

If you take a walk I'll tax your feet ...

In the search for new sources of rents - new components of the private tax base - few areas escaped unscathed. The granting of monopolies was by no means Soeharto's only means of generating and harvesting rents. Apart from smokers and consumers of noodles (that is, a large proportion of the population), rents were extracted from Haj pilgrims, cinema-goers, rattan producers, car drivers and motorcycle riders, travellers returning from overseas, small landholders and so on. Indeed, presidential grandson Ari Sigit came close to putting into effect the idea of 'taxing feet' by attempting to obtain a monopoly on the supply of shoes to all of Indonesia's schoolchildren, although the public outcry forced Soeharto to step in and abort the scheme (Backman 1999:281-2). The range of techniques, some of which have been mentioned already, included the following:

- Protection from imports. In conjunction with licensing to constrain domestic competition, favoured firms were granted protection from imports.

- Awarding contracts without bidding. Private sector firms were awarded contracts by government departments and state enterprises without any genuine bidding process involving competition with other firms.

- Providing access to cheap loans. Favoured firms had ready access to state bank or even central bank loans at highly subsidised interest rates - and were not forced to repay if investments did not turn out well. ${ }^{2}$

- Granting rights to exploit natural resources. The award of rights to exploit natural resources without having to bid or to pay a reasonable level of royalties has been of immense benefit to the Soeharto franchise. Forest concessions are a prime example, as are the Freeport minerals concessions in Irian Jaya.

- Designation as mandatory partners in foreign joint ventures. Just as domestic firms could earn favours by donating shares in themselves to first family members, so foreign firms were willing to pay for the privilege of being permitted to establish new operations in Indonesia - perhaps with special facilities of various kinds - in much the same way.

2 In the course of the crisis it became clear that the state banks were responsible for by far the bulk of bad loans (Pardede, 1999: 26), a large proportion of which were owed by Soeharto family and crony companies (Dow Jones Newswires, 15 June 1999). 
- Rights to take over land. The grant of rights to take over land, in practice without payment of fair compensation to the original occupiers, has been a method often used to generate rents. This has occurred with land around major cities, and also with tracts of forest to be converted into plantations.

- Purchase of inputs at artificially low prices. In many cases firms have been favoured by being permitted to purchase inputs at artificially low prices from state enterprises - if they were paid for at all.

- Favourable treatment by the tax office. The business sector has always been able to reduce the amount of legitimate tax it paid through negotiation of mutually beneficial outcomes with Soeharto franchisees in the tax office. In addition, at various times the Soeharto government made tax holidays available to firms it wanted to favour.

- Rights to collect taxes. In the later years of the Soeharto regime, the rent generation effort at times became so blatant as to encompass the imposition of new taxes collected by first family companies - a small portion of which was supposedly turned over to the government.

\section{Privatising the Laffer Curve}

The no longer fashionable Laffer curve describes the relationship between the tax rate applied to an economic activity and the tax revenue generated (McMullen, 1981-82). As the rate increases, revenue increases - but at a decreasing rate, because the tax discourages the activity in question. Beyond a certain point, this induced shrinkage of the tax base outweighs the impact of further increases in the rate, and revenue begins to decline. Roughly speaking, the trick for the tax gatherer is to find the rate that maximises revenue. The same principle applies to the private sector criminal activity of extorting 'protection money' from legitimate businesses - not surprisingly, if one takes the view that 'taxation is theft'!

An intuitive understanding of this fundamental principle of taxation and extortion differentiates Soeharto from political leaders in a host of other developing countries, who simply stole on a scale so grand as to bring about severe economic declines - usually with the result that they forfeited their hold on power (and sometimes their lives). Soeharto always took the long-term view, in which sustained growth was essential to the flow of rents and, consequently, to his hold on power. In this sense, Indonesia under Soeharto was 'blessed' with a better class of corruption than many other countries - and, indeed, than under his predecessor, Sukarno, whose regime came to be characterised by such excessive government intervention and corruption that entrepreneurship was largely stifled.

An important feature of the business sector is that it is heavily dominated by firms owned by Chinese Indonesians. This small group, only about two or three per cent of the total population, have always suffered the rancour of large sections of the pribumi (indigenous) community. The flagrant manner in which Soeharto and those around him promoted the interests of a few prominent Chinese Indonesian families only served to deepen resentment against this whole minority community, down to the smallest shopkeeper, and to others who had no business 
at all. The legal system did little to protect their interests, and it suited Soeharto and his franchisees to maintain this state of affairs. Given the Chinese Indonesian minority's vulnerability to outbreaks of mob violence and to extortion by neighbourhood thugs, they could always be expected to pay in various ways for protection. (Extortion of pribumi firms was not unknown, of course, but there is little doubt that Chinese Indonesians bore a disproportionate share.) On some occasions the violence that did occur was not spontaneous, but was deliberately engineered in order to create an artificial demand for protection. Nevertheless, Soeharto appreciated the importance of keeping extortion of the business community within tolerable limits.

For the favoured few, rents were generated by the franchise and the harvest shared with it. For the many, however - ethnic Chinese and pribumi alike payments to the franchise were obligatory unrequited transfers. Licences and permits of all kinds were subject to trivially small legal fees and much larger illegal levies. Again, it is no accident that the legal fees were always kept small: this was precisely what was required if the illegal surcharge was to be maximised within the Lafferian constraint.

Soeharto could not safely assume that his own implicit understanding of the Laffer curve was shared throughout the civil service, however. From time to time ministers who became too greedy had to be pulled into line. And in one famous case, the President had to move against the entire Customs Service (Dick, 1985:10), since the scale of its rent harvesting from importers had become so large as to pose a serious impediment to growth of the economy (McDonald, 1980:116). The import inspection function for all shipments over $\$$ US5,000 in value was contracted out to the Swiss firm Société Générale de Surveillance in April 1985. This early example of privatisation (of a function rather than an enterprise) seems to have been a great success from the wider economic viewpoint, but from the perspective of the franchise it was too effective and, over a period of several years, more and more of the work being done by SGS was handed back to the Customs Service (Parker and Hutabarat, 1996:29). The lengthy interruption to the flow of bribes to Customs officials sent a clear message to franchisees throughout the bureaucracy, however, that excessive rent harvesting would not be tolerated.

\section{Why Did the System Collapse?}

It has been argued elsewhere (Fane and McLeod, 1999; McLeod, forthcoming) that the crisis that engulfed Indonesia from mid 1997 can be explained in terms of widespread concerns about the ability of the government to properly manage an adverse macroeconomic shock. Specifically, if it were widely believed that the government might react to such a shock in a manner that would lead to a significant increase in the money supply, then such a belief could turn out to be self-fulfilling, because currency depreciation is the inevitable consequence of a loss of monetary control.

In terms of this analytical framework, the initial shock provided by the unexpected devaluation of the Thai baht in July 1997 caused investors to fear a 
breakdown of monetary control. Investors reacted to this by rushing to buy foreign exchange, and the government responded by allowing the rupiah to devalue. While many observers (including the writer) thought the extent of the early devaluation absurd since the fundamentals did not seem to justify it, ${ }^{3}$ others guessed that the pressures that had been unleashed would result in a monetary blow out. They maintained or increased their net holdings of foreign currency assets, and were soon proven correct. Base money doubled in the space of a few months, and the value of the currency plunged to previously unimagined depths (Pardede, 1999:7, 15).

This quick summary provides a purely economic explanation for the crisis, ignoring the political context. How does it fit with the above outline of the Soeharto regime? With the benefit of hindsight, it can be seen that several aspects of the regime are likely to have contributed strongly.

First, the franchise was dependent to an extraordinary degree on a single individual in his late seventies, and there was every reason to fear a lack of leadership if Soeharto were suddenly no longer in charge. No matter how widely the system may have been despised, it had proven remarkably successful, and most Indonesians had known no other. And for all his genius, Soeharto had failed to arrange for the smooth transfer to a successor of the giant franchise he had built up over three decades. When he fell ill and was forced to cancel a planned overseas visit around the beginning of December 1997 it was the first time that this had happened, and it brought home to people the realisation that the end of the era could be very close indeed (Soesastro and Basri, 1998:20). It was not until this time that the crisis truly began to get out of hand.

To make matters worse, by this time the blatant nature of the first family's rent harvesting activities had become less and less possible to ignore, even by a heavily muzzled press and a compliant parliament. Moreover, the longer Soeharto stayed in power, the more it seemed that he was intent on dynastic rule in which his position would eventually be taken over by one of his children or at least some strong supporter of the first family. His first daughter, Siti Hardiyanti Rukmana, had adopted a very high profile in the 1997 election campaign, and her brother, Bambang Trihatmodjo, already had become treasurer of the Soeharto election machine, Golkar. The notion that the regime might outlive its creator was sufficiently unpalatable as to boost significantly the groundswell of opposition to it, which was amplified by the students and a growing number of vocal individual critics.

Second, the crisis saw Indonesia turn to the international community for assistance - the first time since the mid 1970s it had felt the need to do so - and this punctured the aura of economic invincibility that existed in the mid 1990s. Moreover, having conceded (perhaps unwarrantedly) its inability to deal with the crisis itself, the government (under pressure from Soeharto) then did much that

3 The central bank had been accumulating foreign reserves at a rapid rate for months beforehand in order to prevent appreciation of the currency (McLeod, 1997:22-3). 
created the impression that it would not do all that it had promised its international 'saviour' it would do (Soesastro and Basri, 1998:20). This raised the prospect that financial assistance would be halted and that the loss of the IMF imprimatur would discourage investors from returning to Indonesia - even to purchase assets now available, in theory, at fire sale prices.

Third, there were clear indications that the delicate working relationship between Soeharto and the 'technocrat' group of economics ministers and advisors, including their colleagues in the central bank, was being heavily strained. These economic policy makers had successfully encouraged the international financial institutions to present a long list of demands for microeconomic reform in return for their assistance (Soesastro and Basri, 1998:10-11). These reforms struck at the very heart of the franchise, yet had only the most tenuous connection with overcoming the crisis. In retrospect it is obvious that Soeharto and his franchisees could not have been expected to acquiesce in the face of the wholesale dismantling of the system - the more so, given that there was little if anything to suggest that these measures would assist with recovery. Indications of the strength of resistance came with the mysterious, fatal fire that engulfed the top few levels of the central bank's brand new office building early in December 1997, shortly after the forced closure of 16 private banks, and the purge by the President of the entire Board of Directors of the central bank during the following three months (Kenward 1999b:121-22). Soeharto's appointment of his daughter, Siti Hardiyanti, and of one of his most notorious cronies, Bob Hasan, as ministers in his short-lived March 1998 cabinet, after the crisis was well under way, also sent a clear message that the IMF's attack on the franchise would be strongly defended.

Fourth, the multiple burdens of currency depreciation, very high nominal interest rates and falling private sector and government spending made it certain that widespread corporate distress would soon follow and, in turn, that loans from banks would not be repaid. In the case of the state banks, with their huge portfolios of loans to favoured firms, no one should have been in any doubt that in the time honoured tradition, taxpayers would be called upon to cover the losses, rather than the borrowers. And in the case of the private banks, the near universal practice - at least among the large, conglomerate-owned banks - of lending heavily to affiliated firms meant that their owners had no funds of their own effectively at risk. This can be illustrated with a simple example. If the bank's owners subscribe Rpl billion in capital, but then receive a loan of Rpl billion (or perhaps considerably more) from the bank, they have no funds directly at risk in it. If the bank fails, the only thing they have to fear is claims from its creditors depositors, or the government, if it steps in and covers the bank's losses. Given Indonesia's weak legal environment and corrupt and ineffective bureaucracy, this would have given little cause for concern. Bank owners, therefore, had little reason to do other than walk away from their bank's losses, leaving them for the government to worry about. Thus the absence of the rule of law and the corruption of the state banks meant that banks would not foreclose on defaulters, making it almost inevitable that the central bank would bail them out, and that this would lead to a loss of monetary discipline. (Although it is possible to bail out 
banks without increasing the money supply - see McLeod, forthcoming - such a policy option was overlooked or ignored.)

Clearly then there were important aspects of the system that ultimately made it vulnerable to collapse. Soeharto had ensured that the only powerful institution was the armed forces. Political parties were emasculated; the parliament, the bureaucracy and the law were corrupted; the media were tightly controlled; the union movement was rendered virtually non-existent; and social organisations of all kinds (other than organised Islam) were never permitted to have a major impact. Individuals were drawn into the system or intimidated into accepting it as a fact of life. But although Soeharto could control most things, he could not control capital, which could vote with its feet in that most democratic arena: the global financial market. Capital could leave at any time, partly because of the government's policy since the early 1970 s of keeping the capital account largely open, and partly because Indonesia's strong links with the overseas Chinese business community (especially in Singapore and Hong Kong) made it virtually impossible to do otherwise. It is interesting that the technocrats had persuaded Soeharto to adopt this policy far earlier than other developing countries did so, in order to provide a disciplining measure on macroeconomic management. The policy was all too effective: Indonesia was indeed 'disciplined' by the financial markets when ultimately they concluded that the regime was inherently unstable.

\section{Looking to the Future}

It is easy to point out the main areas of government-business relations in need of reform under the new presidency of Abdurrahman Wahid. In general, the government should cease acting in ways that generate rents for favoured firms. It should minimise its control and regulation of business activity except where there is a clear market failure justification, in order to limit the scope for extortion by government officials. It should minimise its own involvement in business activity, particularly in key fields such as banking and natural resources. It should provide a legal system, encompassing well written laws and a properly functioning court system and police force, to protect property rights. And it should require that banks are adequately capitalised, so that owners have a genuine stake in their prudent management.

To say that these kinds of reforms are highly desirable, however, begs the question as to whether they are likely to be implemented. The Soeharto franchise served its members well, and they will make every effort to maintain it. On the other hand, Indonesia completed the first genuinely democratic popular elections of parliamentary representatives for several decades in June 1999, culminating in the election of new speakers of the People's Consultative Assembly (MPR) and House of Representatives (DPR), and a new President and Vice President. Successful completion of this process appears to signal the dawn of a new era in which the executive is accountable to the parliament and the parliament is accountable to the people. Prospects for the civilianisation of government and for expansion of the rule of law also seem to have improved by virtue of the failure of 
the armed forces to capture any of these four influential positions, and by the considerable weakening of its position in Wahid's first cabinet.

Reform, and the realisation of genuine and lasting democracy, could be hastened by radical change in the salary structure of the civil service and the military, combined with far greater emphasis on accountability and on reducing opportunities for corruption. As argued above, low salaries are bound to attract relatively many of the kinds of individuals who are willing to become active members of the franchise. Market related salaries, on the other hand, would attract many more people who would be satisfied with their formal remuneration, and therefore not use their time to augment it in the ways outlined here: in short, they would see themselves as employees, rather than franchisees. In contrast, former Finance Minister Mar'ie Muhammad has argued that greed, rather than low salaries, is the cause of corruption, so that raising salaries will not solve the problem (Kompas, 19 January 2000). This misses the point that, because of its low salaries, the civil service attracts disproportionately many individuals willing to engage in corrupt behaviour. He is correct, however, in arguing that raising salaries alone is not enough to have had much of an impact.

The suggestion that higher level salaries should be increased by orders of magnitude, while those at the lower level should be held constant if not actually reduced, is typically met with stares of incredulity: the budgetary consequences would be intolerable; it would be unfair to those in the lower echelons; and it would be contrary to the (greatly overstated) public sector ethos of sacrificing one's personal interests in order to serve the people. But those who have supported the current salary structure while railing against the corruption, collusion and nepotism of the Soeharto regime would do well to ponder their own unwitting contribution to maintaining it.

In making value judgements about the 'fairness' of civil service salaries, presumably it is horizontal comparisons with private sector salaries rather than vertical comparisons within the civil service that should provide the focus. And the basis for the view that civil servants should be expected to sacrifice their own interests for the benefit of the wider public, many of whom are far better off, is difficult to discern. Moreover, a large part of the budgetary cost of civil service salary reform could be recouped by reducing the number of low level employees, who are widely regarded as being greatly underemployed. This reflects the fact that the civil service has been used to buy support by providing jobs, and that much of the work of the civil service is directed to generating revenues for the franchise, rather than promoting the interests of the general public. (Of course, reductions in civil service employee numbers would have the added benefit of reducing office accommodation costs.)

Thus if far reaching reform is to be achieved by the new government, it will need to effect very large salary increases for those at the higher levels of the bureaucracy and the military - while simultaneously making it plain, and acting to ensure, that the ways of the past are to undergo enormous change along the lines indicated. Unfortunately, however, in current circumstances in which the civil service and the state enterprises are reviled for their corruption, and the 
military for having brought shame on the nation by its actions in East Timor, such a strategy is unlikely to commend itself. ${ }^{4}$

\section{References}

Backman, M. (1999), Asian Eclipse: Exposing the Dark Side of Business in Asia, Wiley, Singapore.

Cribb, R. (ed.) (1990), The Indonesian Killings of 1965-1966: Studies from Java and Bali, Centre of Southeast Asian Studies, Monash University, Clayton.

Crouch, H. (1979), 'Patrimonialism and Military Rule in Indonesia', World Politics 31(4):571-587.

Dick, H. (1985), 'Survey of Recent Developments', Bulletin of Indonesian Economic Studies XXI(3):1-29.

Fane, G. and R. McLeod (1999), 'Lessons for Monetary and Banking Policies from the 1997-98 Economic Crises in Indonesia and Thailand', Joumal of Asian Economics 10(3):395-413.

Harrison, G. (1966), 'Taxman', from The Beatles' album Revolver, Parlophone.

Hill, H. (1996), The Indonesian Economy Since 1996: Southeast Asia's Emerging Giant, Cambridge University Press, Cambridge.

Kenward, L. (1999a), 'Assessing Vulnerability to Financial Crisis: Evidence from Indonesia', Bulletin of Indonesian Economic Studies 35(3): 71-95.

Kenward, L. (1999b), 'What Has Been Happening at Bank Indonesia?', Bulletin of Indonesian Economic Studies 35(1): 121-127.

Kreuger, A. (1974), 'The Political Economy of the Rent-Seeking Society', American Economic Review 64(3):291-303.

McDonald, H. (1980), Suharto's Indonesia, Fontana Books, Blackburn.

McLeod, R. (1997), 'Survey of Recent Developments', Bulletin of Indonesian Economic Studies 33(1):3-43.

McLeod, R. (1998), 'Indonesia', pp. 31-48 in R. McLeod and R. Garnaut (eds), East Asia in Crisis: From Being a Miracle to Needing One?, Routledge, London and New York.

4 The former regent of Padang Pariaman district and his assistant were imprisoned after being found guilty of swindling Rp1.1 billion (about $\mathrm{A} \$ 230,000$ ) of state funds from a project to build a bus terminal (Jakarta Post, 8 February 2000). Such an outcome rarely occurred under Soeharto, and so is to be welcomed, but it should be noted that the sentence of one year in jail is slight in comparison with the amount involved. 
McLeod, R. (forthcoming), 'Lessons from Indonesia's Crisis', in D. Wilson, D. Dasgupta and M. Uzan (eds), Capital Flows Without Crisis: Reconciling Capital Mobility and Economic Stability, Routledge, London and New York.

McMullen, B. Starr (1981-82), 'The Laffer Curve: Fact or Convenient Fantasy', Economic Forum 12(2):113-115.

Pardede, R. (1999), 'Survey of Recent Developments', Bulletin of Indonesian Economic Studies, 35(2):3-39.

Parker, S. and P. Hutabarat (1996), 'Survey of Recent Developments', Bulletin of Indonesian Economic Studies 32(3):3-31.

Robison, R. (1986), Indonesia: The Rise of Capitalism, Allen and Unwin, Sydney.

Sadli, M. (1993), 'Recollections of My Career', Bulletin of Indonesian Economic Studies, 29(1):35-51.

Schwarz, A. (1999), A Nation in Waiting: Indonesia's Search for Stability, Allen and Unwin, Sydney.

Soesastro, H. and M. Chatib Basri (1998), 'Survey of Recent Developments', Bulletin of Indonesian Economic Studies 34(1):3-54.

Transparency International (1999), 'New Poll Shows Many Leading Exporters Using Bribes', Press Release, 26 October, http://www/transparency.de/documents/cpi/index.html, accessed 27 October 1999.

This paper is a much shortened version of Ross H. McLeod, 'GovernmentBusiness Relations in Indonesia During the Soeharto Era and Beyond', in $P$. Drysdale (ed.), 'Reform and Recovery in East Asia: The Role of the State and Economic Enterprise', Routledge, (forthcoming). The author is grateful to two anonymous referees and to participants at a seminar at the ANU in September 1999 for helpful comments. 